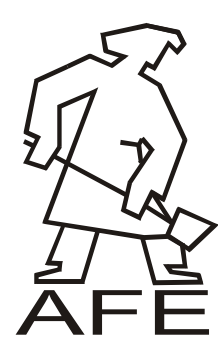

\title{
Moulding Sands with New Inorganic Binders - Ecology Assessment in the Aspect of Work Environment
}

\author{
I. Szanda ${ }^{\text {a }}$ M. Żmudzińska ${ }^{a}$, J. Faber ${ }^{\text {a }}$, K. Perszewska ${ }^{a}$ \\ ${ }^{a}$ Foundry Research Institute, Zakopiańska 73, 30-418 Krakow, Poland \\ * Corresponding author. E-mail address: irsza@iod.krakow.pl
}

Received 16.04.2012; accepted in revised form 02.07.2012

\begin{abstract}
The development of economy and industry introducing new technologies and materials often means the increased threat of occurrence of factors harmful to humans and environment. Workers employed in foundries as mould pourers are the group of high professional risk.

Foundry moulding sands when poured with liquid metal are a source of the emission of harmful, toxic and carcinogenic (benzene, PAHs) compounds.

The paper presents the results of studies on the concentration of chemical compounds emitted in the process of casting aluminium alloy and brass using moulding sands with the new inorganic binders. The specific values of the exposure indices were compared with the limit values. This enabled an assessment of the impact of moulding sands on work environment. The obtained results were compared with the values of contaminants emitted when pouring foundry moulds made from furan sands and bentonite sands with an addition of coal dust.
\end{abstract}

Studies were carried out under the project POIG.01.01.02-00-015/09 "Advanced materials and technologies."

Keywords: Innovative materials and technologies, Casting, Moulding sands, Inorganic binders, Work environment

\section{Introduction}

Casting is the activity dominated by high-temperature processes and, therefore, the search for new moulding materials ensuring the highest quality of castings produced, on the one hand, and the lowest level of emissions, on the other, is stil going on. Moulding sand is one of the basic materials (often containing organic compounds) used to make foundry moulds, necessary in most of the casting manufacturing processes and exposed to the direct contact with liquid metal. During casting, harmful compounds are emitted from moulding sand; this mainly occurs during pouring of moulds with liquid metal and during the solidification and cooling of castings.

With constantly increasing requirements for environmental protection, new importance are gaining these technologies that, while ensuring the required technological parameters, can also provide the least possible harmfulness to the environment [1-6].

The purpose of the executed structural project is to introduce to the production of foundry moulds and cores, new ecological binders to replace the, used so far for casting of non-ferrous metal alloys, bentonite sands and resin-bonded sands. The waste materials from these technologies have a negative impact on the environment $[7,8]$.

Based on the results of the research carried out under the project, the following binders were selected for further tests and studies related with their impact on ecology $[9,10]$ :

- binder "A" modified with thermoplastic synthetic polimer $(1 \%)$, 
- $\quad$ binder "B" modified with copolymer obtained by emulsion polymerisation $(1 \%)$, and were considered potentially the most beneficial for casting of non-ferrous metals.

The batches of binders for laboratory tests were prepared under laboratory conditions by the manufacturer of inorganic binders. Studies were carried out on moulding sands prepared with the new modified inorganic binders hardened with ethylene glycol diacetate $(2.5$ parts by weight of binder and $10 \%$ of hardener in respect of the binder weight) and, for comparison, on sands with an organic binder (furan sand) and with bentonite and coal dust.

These sands were assessed in terms of their impact on ecology, using them for test moulds and carrying out studies enabling determination of the evolution rate of gaseous pollutants in the process of mould pouring and during casting solidification and cooling. The developed procedure for testing of moulding sands allowed the determination of the amount of chemical compounds emitted under real conditions, comparable to a typical casting process.

\section{Own research}

Studies carried out at the Foundry Research Institute included measurements of the concentration of chemical compounds emitted in the process of mould pouring and casting cooling (solidification) at an experimental station for casting of non-ferrous metals. Two series of tests were conducted. During the first series, moulds and cores made from the sands based on the new inorganic binders were poured with aluminium (castings made from the AK9 alloy), while in the second series, the moulds were poured with brass (castings made from the MO59 alloy). From the sands as described above, moulds of dimensions $320 \times 250 \times 100 / 100$ were made.
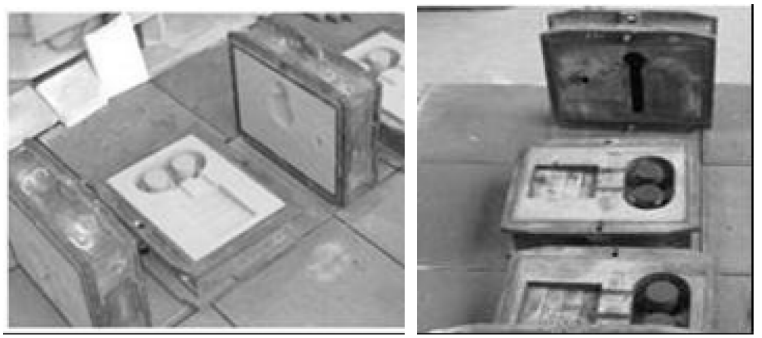

Fig. 1. Testing moulds

The photographs below show pouring of moulds with liquid metal on the test station. The temperature of the liquid AK9 alloy before removing the crucible from the furnace and pouring of moulds was $730^{\circ}$ $\mathrm{C}$, the mass of metal in the mould after casting was about $3.0 \mathrm{~kg}$. The temperature of the liquid MO59 alloy before removing the crucible from the furnace and pouring of moulds was $1130^{\circ} \mathrm{C}$, the mass of metal in the mould after casting was about $8 \mathrm{~kg}$.
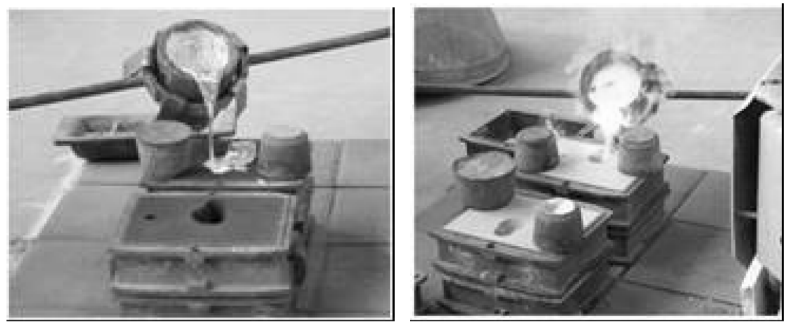

Fig.2. Testing moulds pouring

For comparison, studies on the emission of harmful substances from moulding sands were conducted on mixtures with furan resin and on mixtures with bentonite and coal dust.

\subsection{Test methods (series I and II)}

The method for collecting the gaseous pollutants on the test station is shown in the photographs below. The ready mould was poured with liquid metal, and immediately after this operation it was covered with a shielding cone (hood). The samples of the air to determine the concentration of selected chemical compounds emitted during pouring of mould with molten metal and cooling of the casting were collected at the gas outlet from the installed shielding cone, using scrubbers with absorbing solutions (phenol, formaldehyde, ammonia) and tubes filled with sorbent, selected according to the analytical method applied. The concentrations of carbon monoxide, nitrogen oxide, nitrogen dioxide and sulphur dioxide were determined by direct measurement.
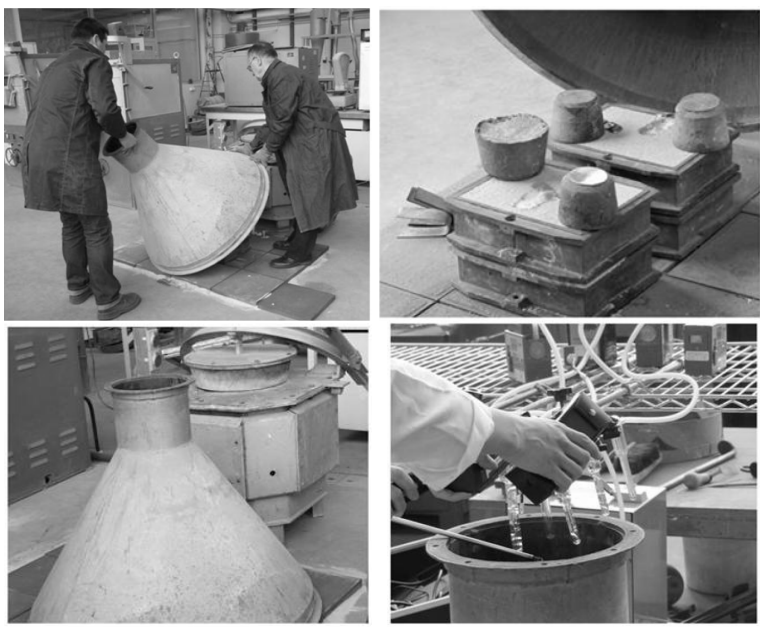

Fig. 3. Test station

For air sampling to determine the concentrations of phenol, formaldehyde, ammonia, acetic acid and ethylene glycol, a Gilair-3 aspirator was used; the concentrations of benzene, toluene, xylene, furfurol, PAHs, ethyl acetate and acetaldehyde were determined with a Gillian LFS-113DC aspirator.

The sampled air was analysed chemically. The concentrations of phenol, formaldehyde and ammonia were determined by spectrophotometry, and those of benzene, toluene, xylene, furfurol, 
PAHs, acetic acid, ethylene glycol, ethyl acetate and acetaldehyde by gas chromatography.

The concentrations of carbon monoxide, nitrogen oxide and nitrogen dioxide were determined with Multigas Meters type III, while the concentration of sulphur dioxide was determined with a SafeLog 100 measuring device.

\subsection{The legal basis}

The legal regulations controlling the maximum concentration of the determined substances in the air in workplace are given below.

Regulation of the Minister of Labour and Social Policy of 29 November 2002 on maximum permissible concentrations and intensities of harmful factors in workplace - Journal of Laws No. 217, item1833, Annex 1A [11] with the following amendments: Regulation of the Minister of Economy and Labour of 10 October 2005 - Journal of Laws No. 212, item 1769, Regulation of the Minister of Labour and Social Policy of 30 August 2007 - Journal of Laws No. 161, item 1142, Regulation of the Minister of Labour and Social Policy of 16 June 2009 - Journal of Laws No. 105, item 873, Regulation of the Minister of Labour and Social Policy of 29 July 2010 - Journal of Laws No. 141, item 950, Regulation of the Minister of Labour and Social Policy of 16 December 2011 - Journal of Laws No. 274, item 1621.

\subsection{Identifying the exposure indicators}

The measured values of the concentration of chemical compounds emitted in the process of mould pouring with liquid metal and during the solidification and cooling of casting were used as a basis for calculation of the exposure indicators $\mathrm{Cw}$ (weighted average concentrations per work shift) and the coefficients of total exposure [12].
The exposure indicator characterises worker exposure to harmful substance. It is calculated from the concentration of a chemical compound, determined in the air in workplace and compared further with the values given in hygienic norms (MAC).

Total exposure is calculated when the worker is exposed simultaneously or sequentially to the effect of several substances of similar toxicity. Deviations from this procedure apply to cases of antagonistic or carcinogenic effect. Therefore, to assess total exposure, the carcinogenic compounds, i.e. benzene and PAHs emitted when pouring with liquid metal the furan sands and bentonite sands with coal dust, were not considered.

The coefficient of total exposure is calculated as a sum of the concentration ratios of individual substances and their corresponding MAC values, and it should not exceed the value equal to 1 .

TWA - the maximum allowable concentration - is an average weighted value of concentration, the impact of which on the worker during a normal 8-hour work day and an average weekly working time should not throughout the period of his professional activity cause any negative changes in the worker's health and in the health of his future generations.

TWA15 - the maximum instantaneous allowable concentration - is an average weighted value of concentration that should not cause any negative changes in the worker's health, if occurring in the work environment for a time not longer than 15 minutes and with a frequency not higher than 2 times per work shift, at intervals of not less than 1 hour.

The instantaneous concentrations were determined by taking two 15-minute samples in the measurement period, during which particularly high concentrations of the examined substance were expected.

The results of experimental studies conducted on a stand for casting of aluminium (series I) and brass (series II) are given in Tables 1 and 2 below.

Table 1

The emission of pollutants during casting of aluminium alloy - series I - related to limit values

\begin{tabular}{|c|c|c|c|c|c|c|c|c|c|c|}
\hline $\begin{array}{l}\text { Type of tested } \\
\text { moulding sand }\end{array}$ & $\begin{array}{l}\text { The emitted } \\
\text { compound }\end{array}$ & $\begin{array}{c}\text { Exposure } \\
\text { indicator } \\
\mathrm{c}_{\mathrm{w}} \\
\mathrm{mg} / \mathrm{m}^{3}\end{array}$ & $\begin{array}{l}\text { TWA } \\
\mathrm{mg} / \mathrm{m}^{3}\end{array}$ & $\mathrm{c}_{\mathrm{w}} / \mathrm{TWA}$ & $\begin{array}{r}\text { Instant } \\
\text { concer } \\
\mathrm{ms}\end{array}$ & $\begin{array}{l}\text { leous } \\
\text { ations } \\
n^{3}\end{array}$ & $\begin{array}{l}\mathrm{TWA}_{15} \\
\mathrm{mg} / \mathrm{m}^{3}\end{array}$ & $\mathrm{C}_{\mathrm{ch}} / \mathrm{T}$ & $\mathrm{VA}_{15}$ & $\begin{array}{l}\text { N-tuple of } \\
\text { total } \\
\text { exposure }\end{array}$ \\
\hline \multirow{5}{*}{$\begin{array}{l}\text { moulding sand } \\
\text { based on } \\
\text { binder } \mathbf{A} \\
\text { and hardener } \mathbf{F}\end{array}$} & acetic acid & 0.4 & 15 & 0.03 & 0.6 & 0.7 & 30 & 0.02 & 0.02 & \multirow{5}{*}{1.9} \\
\hline & ethylene glycol & 9.9 & 15 & 0.7 & 34.6 & 9.7 & 50 & 0.7 & 0.2 & \\
\hline & ethyl acetate & 4.0 & 200 & 0.02 & 4.6 & 3.5 & 600 & 0.008 & 0.006 & \\
\hline & nitric oxide & 0.16 & 3.5 & 0.05 & 0.17 & 0.13 & 7.0 & 0.02 & 0.02 & \\
\hline & nitrogen dioxide & 0.22 & 0.7 & 0.31 & 0.19 & 0.19 & 1.5 & 0.20 & 0.20 & \\
\hline \multirow{4}{*}{$\begin{array}{l}\text { moulding sand } \\
\text { based on binder } \\
\text { B } \\
\text { and hardener } \mathbf{F}\end{array}$} & formaldehyde & 1.1 & 0.5 & 2.2 & 0.8 & 0.5 & 1.0 & 0.8 & 0,5 & \multirow{4}{*}{2.4} \\
\hline & acetic acid & 0.6 & 15 & 0.04 & 0.6 & 0.6 & 30 & 0.02 & 0,02 & \\
\hline & ethylene glycol & 23 & 15 & 1.5 & 61.7 & 32.0 & 50 & 1.2 & 0.6 & \\
\hline & nitrogen dioxide & 0.22 & 0.7 & 0.31 & 0.19 & 0.19 & 1.5 & 0.13 & 0.13 & \\
\hline moulding sand & phenol & 1.9 & 7.8 & 0.2 & -- & -- & -- & -- & -- & \\
\hline
\end{tabular}




\begin{tabular}{|c|c|c|c|c|c|c|c|c|c|c|}
\hline \multirow{6}{*}{$\begin{array}{l}\text { based on furan } \\
\text { resin }\end{array}$} & ammonia & 12.3 & 14 & 0.9 & 10.5 & 10.0 & 28 & 0.4 & 0.4 & \multirow{6}{*}{4.6} \\
\hline & carbon monoxide & 10.8 & 23 & 0.5 & 13.1 & 13.9 & 117 & 0.11 & 0.12 & \\
\hline & nitrogen dioxide & 0.35 & 0.7 & 0.50 & 0.43 & 0.43 & 1.5 & 0.29 & 0.29 & \\
\hline & benzene & 4.6 & 1.6 & 2.9 & -- & -- & -- & -- & -- & \\
\hline & toluene & 31.4 & 100 & 0.3 & 49.5 & 34.9 & 200 & 0.2 & 0.2 & \\
\hline & xylene & 4.5 & 100 & 0.04 & -- & -- & -- & -- & -- & \\
\hline \multirow{5}{*}{$\begin{array}{l}\text { Moulding sand } \\
\text { with bentonite } \\
\text { and coal dust }\end{array}$} & phenol & 1.4 & 7.8 & 0.2 & -- & -- & -- & -- & -- & \multirow[b]{5}{*}{2.5} \\
\hline & carbon monoxide & 12.8 & 23 & 0.6 & 18.1 & 12.3 & 117 & 0.15 & 0.10 & \\
\hline & nitric oxide & 0.28 & 3.5 & 0.08 & 0.21 & 0.27 & 7.0 & 0.03 & 0.04 & \\
\hline & nitrogen dioxide & 0.29 & 0.7 & 0.41 & 0.24 & 0.19 & 1.5 & 0.16 & 0.13 & \\
\hline & sulphur dioxide & 2.8 & 1.3 & 2.1 & 2.7 & 2.7 & 2.7 & 1.0 & 1.0 & \\
\hline
\end{tabular}

Table 2

The emission of pollutants during casting of brass - series II - related to limit values

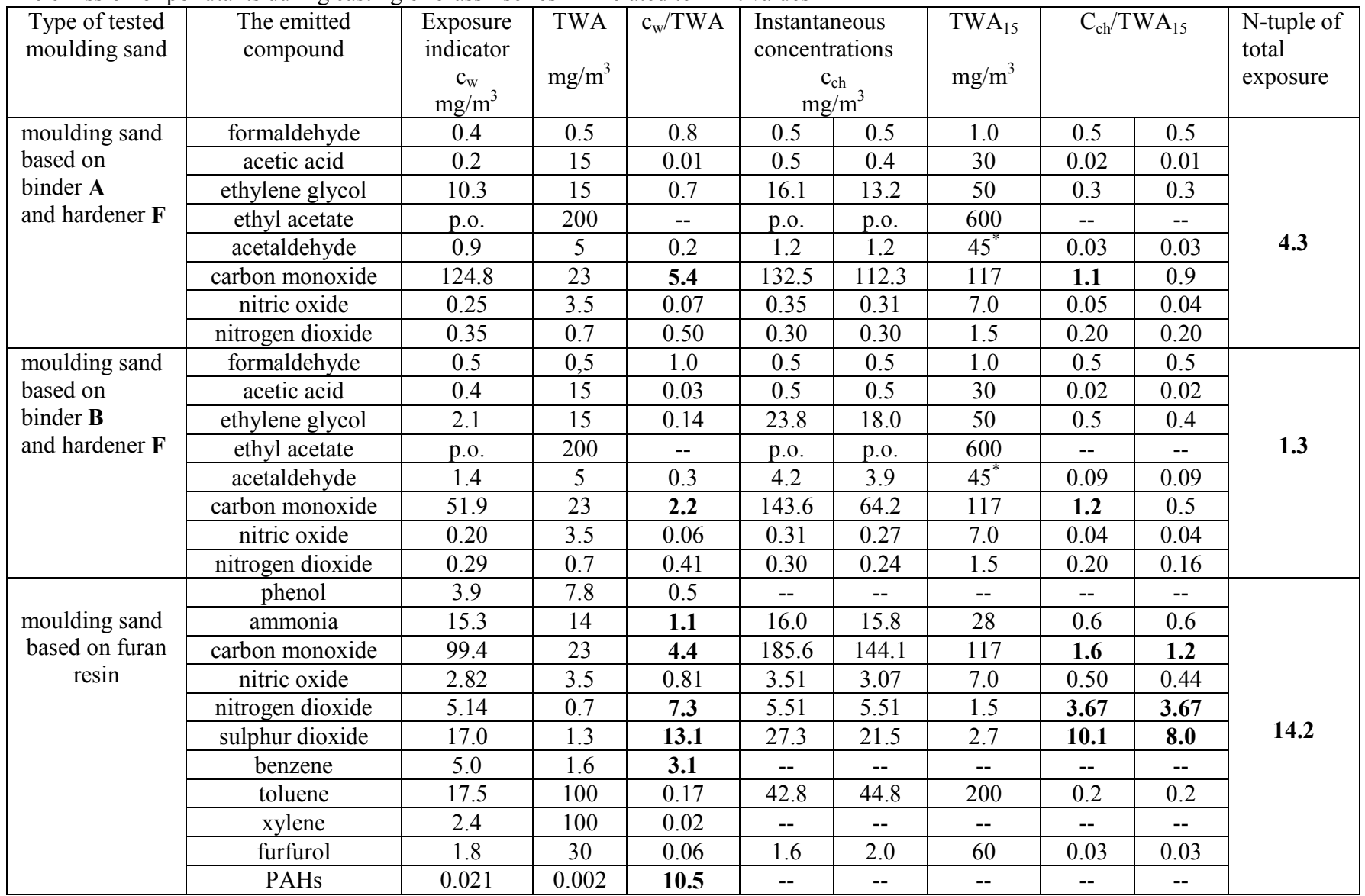


Graphs 1 and 2 below show the comparison of cumulative exposure coefficients for the studied moulding sands.

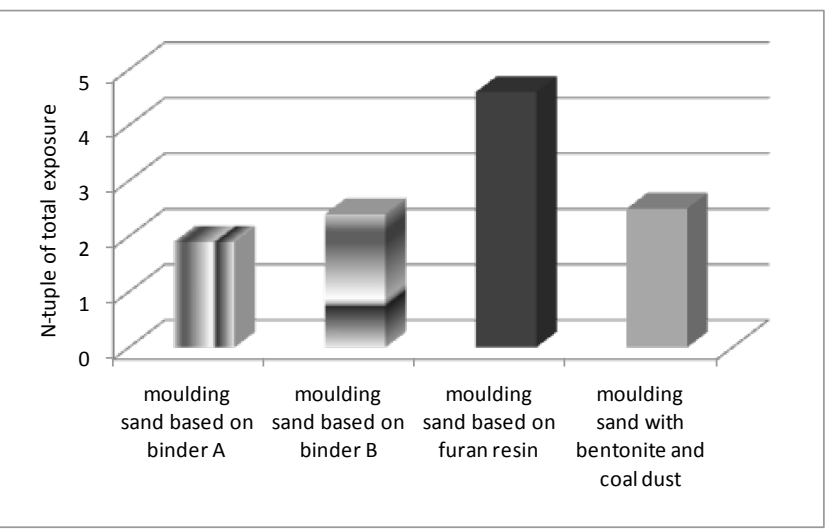

Graph 1. Comparison of the coefficients of the total exposure of workers to chemicals emitted during casting of aluminium alloy (series I)

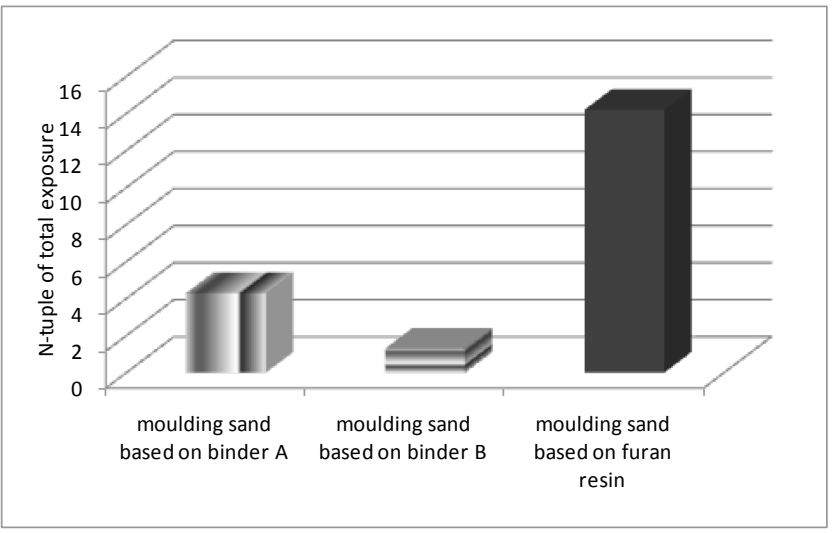

Graph 2. Comparison of the coefficients of the total exposure of workers to chemicals emitted during casting of brass (series II)

\section{Ecology assessment of the examined sands in terms of the work environment}

Based on the conducted tests and examinations and the results obtained, it was found that the lowest threat for the foundry workers employed as mould pourers create the sands with inorganic binders. When pouring aluminium into moulds made from the sand based on a new inorganic binder $\mathrm{A}$, only the allowable limit value of formaldehyde was found to be exceeded, and in the case of the sand based on binder $\mathrm{B}$, the allowable limit value of formaldehyde and ethylene glycol. During casting of brass, in both cases of the sands with binders $A$ and $\mathrm{B}$, the allowable limit values of carbon monoxide concentrations were exceeded.

Using furan sand for casting of aluminium resulted in exceeding the hygienic norms for sulphur dioxide and benzene. In the case of brass casting, the allowable concentrations of ammonia, carbon monoxide, nitrogen dioxide, sulphur dioxide, benzene, and total PAHs were exceeded.

Aluminium cast to bentonite sand moulds with an addition of coal dust gave exceeded limit values of sulphur dioxide, benzene and total PAHs.

It should be noted that the applied method for testing the gaseous emissions on a pilot work stand enabled measurements under extreme conditions, i.e. without an effectively operating ventilation system, which considerably affected the results of the measurements.

The emitted pollutants adversely affect the health of the foundry workers. Benzene is a toxic and carcinogenic substance, producing also narcotic effects. PAHs are toxic and carcinogenic compounds. Ammonia is toxic. Formaldehyde is a toxic substance of irritating, possibly carcinogenic effects. Ethylene glycol is harmful. Carbon monoxide is a toxic substance, creating a serious risk to health. Nitrogen dioxide and sulphur dioxide are both toxic and caustic substances.

Summing up it can be stated that the least harmful in terms of work environment are the investigated sands based on the new modified inorganic binders. Organic modifying additives have no adverse effect on these sands in terms of their impact on the work environment.

\section{Summary}

- The applied procedure allowed measurements to determine the maximum amount of gaseous pollutants emitted from the tested moulding sands. Under the real conditions of the pouring process, lower concentrations of the emitted substances are to be expected as most foundries are using an effectively operating equipment for environmental protection (ventilation system at each work post).

- The source of the pollutants emitted by the investigated sands based on new inorganic binders is the applied ester hardener.

- To reduce harmful emissions from the casting processes it is recommended to strive at the use of inorganic binders and elimination of coal dust from the mould-making technology.

\section{Acknowledgements}

The paper presents the results of studies conducted under the Project POIG.01.01.02-00-015/09 "Advanced Materials and Technologies", Area VII, Task 3 "Ecological technologies to manufacture moulds and cores for casting of non-ferrous metals including their recycling and utilisation" co-financed by the European Union and the state budget.

\section{References}

[1] Holtzer, M. \& Grabowska, B. (2008). Modern sands with inorganic binders," In XI Foundry Conference Technical, 29-31 may 2008 (pp. 93-98). Nowa Sól.

[2] Lewandowski, J.L. (2003). The state of the application of inorganic binders. Przeglad Odlewnictwa. 10, 373-375. 
[3] Baliński, A. (2009). About structure of hydrated sodium silicate as a binder of moulding sands, Cracow: Foundry Research Institute.

[4] Löchte, K. \& Boehm, R. (2006). Properties and expierence of an inogranic binder, Foundry Trade Journal. 180 (1), 28.

[5] Izdebska-Szanda, I., Pezarski, F. \& Smoluchowska, E. (2008). Investigating the kinetics of the binding process In moulding sands using new, environment-friendly, inorganic binders, Archives of Foundry Engineering. 8 (2), 61-66.

[6] Pezarski, F., Izdebska-Szanda, I. \& Smoluchowska, E. (2008). Research on improving the properties and applicability of new inorganic binders in the manufacture of environment-friendly foundry moulds and cores. Prace Instytutu Odlewnictwa XLVIII. (2), 48-56.

[7] Multi-author work (2005). A guide for the best available techniqes (BAT) - recommendations for foundry sector, Ministerstwo Środowiska.
[8] Multi-author work (2005) Integrated Pollution Prevention and Control Reference Document on Best Available Techniques in the Smitheries and Foundries Industry.

[9] Izdebska-Szanda, I., Szanda, M. \& Matuszewski, S. (2011). Technological and ecological studies of moulding sands with new inorganic binders for casting of non-ferrous metal alloys, Archives of foundry Engineering. 11 (1), 43-48.

[10] Izdebska-Szanda, I. \& Baliński, A. (2011). New generation of ecological silicate binders, ELSEVIER, http://dx.doi.org/10.1016/j.proeng.2011.04.146. DOI: 10.1016

[11] Regulation of the Minister of Labour and Social Policy of 29 November 2002 on maximum permissible concentrations and intensities of harmful factors in workplace - Journal of Laws No. 217, item 1833, Annex 1A.

[12] Polish Standard PN-Z-04008-7: 2002 Protection of air purity. Sampling. Principles of air sampling in the workplace and interpretation of results and the change of PN-Z-04008-7: 2002/Az1: 2004. 